\title{
Money and the Rule of Law in Ecuador
}

\author{
STEVE H. HANKE* \\ The Johns Hopkins University and The Cato Institute
}

(Received September 2003; In final form November 2003)

\begin{abstract}
The rule of law is defined and its implications in the monetary sphere are elaborated. When national monetary arrangements fail to comport with the rule of law, "dollarization" is desirable. That policy provides for more stable money and expectations about its future value. The salutary effects of Ecuador's "dollarization" program of 2000 are reviewed. In addition, a manifesto for economic reform in Ecuador is presented. Its elements are: financial integration, fiscal transparency and control, tax simplification and reform, supermajority voting, deregulation, and privatization.
\end{abstract}

Key words: Dollarization, The Rule of Law, Financial Integration, Transparency, Deregulation, Privatization

JEL Codes: O17; O24; O54

\section{INTRODUCTION}

What is the rule of law? The concept originated with the Greek Democracy. The premiere Hellenist Jacqueline de Romilly captured the essence of the idea by stating that "The Greeks, jealous of their independence, were always proud to proclaim their submission to Laws. ... They demanded only that their city be ruled by its own Laws and not by a man. The Law was thus the basis and the guarantor of all their political life." (de Romilly, 2001, p. 1)

That classical concept was ordered, classified, and elaborated on by Aristotle, and later the Romans lent practical aspects to the rule of law. Since then, it has been debated and adapted to modern times. For example, the American Constitution and Bill of Rights are short and clear and serve as a model for those who aspire to order, freedom, and the rule of law. (Niskanen, 2003) The Bill of Rights is notable because with one exception, the right to a trial by jury, it lists the rights of individuals against infringements by the state, rather than claims by individuals on goods and services to be provided by the state. The thrust of the American model, therefore, comports with the rule of law in the classical sense because the state is subjected to a fixed set of rules that delimit the scope of its coercive powers. Individuals and their property are protected from the arbitrary, ad hoc actions of the state and other individuals. In consequence, individuals can plan their activities within the confines of known, fixed "rules of the game." This allows people to pursue their personal ends, as long as their actions do not infringe on the broadly-defined property rights of their fellow citizens. (Hayek, 1944, pp. 72-87)

\footnotetext{
* Corresponding author. Professor of Applied Economics, The Johns Hopkins University, Baltimore, MD 21218-2686 USA and Senior Fellow at the Cato Institute in Washington, DC, USA. E-mail: hanke@jhu.edu
} 
In addition to formal written laws, the apostles of liberty never fail to stress that ingrained moral beliefs serve as a cornerstone of a free society. These unwritten rules have evolved over time and serve as a necessary, but not sufficient, condition for freedom to blossom. Accordingly, the general observance of established habits, traditions and moral conventions is as important as written laws for a free society. (Hayek, 1960, p. 62)

Not all laws conform with the rule of law, however. For example, general rules of the road, or highway codes, do. But laws which dictate personal ends-like obliging all motorists to drive from one town to another-do not.

To determine what laws comport with the rule of law principles causes no end of confusion, particularly for people who have lived under communist regimes. (Wedel, 2001) When I explain the importance of introducing the rule of law in former communist countries, most people ask: Why? After all, they explain, we have laws - lots of laws — and under communism, we had even more laws. There were laws governing everything. This confusion was clarified by Hayek:

\footnotetext{
But to call 'law' everything that the elected representatives of the majority resolve, and to describe as 'Government under the Law' all the directives issued by them-however discriminating in favor of, or to the detriment of, some groups of individuals - is a very bad joke. It is in truth lawless government. It is a mere play on words to maintain that, so long as a majority approves of acts of government, the rule of law is preserved. The rule of law was regarded as a safeguard of individual freedom, because it meant that coercion was permissible only to enforce obedience to general rules of individual conduct equally applicable to all, in an unknown number of future instances. Arbitrary oppression - that is coercion undefined by any rule by the representatives of the majority - is no better than arbitrary action by any other ruler. Whether it requires that some hated person should be boiled or quartered, or that his property should be taken from him, comes in this respect to the same thing. Although there is good reason for preferring limited democratic government to a non-democratic one, I must confess to preferring non-democratic government under the law to unlimited (and therefore essentially lawless) democratic government. Government under the law seems to me to be the higher value, which it was once hoped that democratic watch-dogs would preserve. (Hayek, 1984, p. 354)
}

In light of the fact that most people reflexively chant the glories of democracy without knowing why, Hayek's preference (and my own) for non-democratic governments under law to "lawless" democratic governments merits further comment. To understand the vacuity of the democracy dogma, let us consider the case of Hong Kong. It was ceded by China to Britain in 1842. Subsequently, Hong Kong became a British colony—not a democracy—and was governed as such until July 1, 1997. During Hong Kong's colonial era, its government adhered to the rule of law. In consequence, in the last year of its non-democratic, colonial status (1997), Hong Kong was ranked as the world's most free economy. (Holmes et al., 1997) These facts illustrate Hayek's point, namely that democracy is not a precondition for the application of the rule of law and the attainment of freedom in the economic sphere. (Barro, 2000) Incidentally, money in Hong Kong was (and is) governed by a rule-based, though not fully orthodox, currency board regime, one that is related to Ecuador's "dollarized" regime. (Hanke, 2002a)

To further clarify and operationalize the general idea of the rule of law, it is helpful to itemize the principles that can be derived from the idea, as Joseph Raz has done (1979, pp. 7-12):

- All rules should be prospective, open and clear.

- Laws should be relatively stable.

- The making of particular laws (particular rules or legal orders) should be guided by open, stable, clear and general rules.

- The independence of the judiciary must be guaranteed.

- The courts should have review powers over the implementation of other principles to ensure conformity to the rule of law.

- The courts should be easily accessible.

- The discretion of crime-preventing agencies should not be allowed to pervert the law. 


\title{
2 MONEY AND THE RULE OF LAW
}

When properly applied, the rule of law guarantees freedoms in the economic, political, intellectual and moral spheres. (Machlup, 1970, p. 137) In the economic sphere, money constitutes an important element. Ludwig von Mises dealt at length with this issue in The Theory of Money and Credit, which was published originally in 1912:

\begin{abstract}
It is impossible to grasp the meaning of the idea of sound money if one does not realize that it was devised as an instrument for the protection of civil liberties against despotic inroads on the part of governments. Ideologically it belongs in the same class with political constitutions and bills of rights. The demand for constitutional guarantees and for bills of rights was a reaction against arbitrary rule and the non-observance of old customs by kings. The postulate of sound money was first brought up as a response to the princely practice of debasing the coinage. It was later carefully elaborated and perfected in the age which-through the experience of the American Continental Currency, the paper money of the French Revolution and the British Restriction period-had learned what a government can do to a nation's currency system. (von Mises, 1971, p. 414)
\end{abstract}

Given Germany's experience with hyperinflation in the 1920s, it is not surprising that members of the Freiburg School (Ordo-liberals) elaborated on the money_rule of law nexus after the Second World War. For example, Walter Eucken, the founder of the Freiburg School, laid great stress on the rule of law and the primacy of a currency policy to safeguard the stability of the value of money. (Sally, 1998, p. 111-12).

When stripped of all its technicalities, the money - rule of law nexus is nothing more than a matter of property rights. If a government is in possession of a devaluation option, those who own money issued by the government face the prospect of having their property rights confiscated in an arbitrary, ad hoc manner via devaluations. Accordingly, governments that fail to protect the value of their money are guilty of not abiding by the rule of law.

Argentina's recent experience illustrates this point. Under the convertibility system, which was established on April 1, 1991, the government made an explicit redemption pledge. Each person who owned an Argentine peso was guaranteed the right to convert a peso for a US dollar. To make this redemption pledge credible, the Convertibility Law required the government to hold US dollar reserves at the central bank that, under most circumstances, would equal or exceed the value of the pesos the central bank had emitted. (I have discussed this at length in Hanke, 1999c) When the Convertibility Law was revoked by decree on January 6, 2002, the peso was devalued, the peso was allowed to float and the redemption pledge was rendered null and void. In consequence, the government confiscated $\$ 17.8$ billion of central bank reserves that had been the property of people who held pesos at the time of the devaluation. (Hanke, 2003)

What, then, is a country to do if it has a history of not adhering to the rule of law and is incapable of safeguarding the value of its domestic currency? The answer is obvious. It should abandon its domestic currency and replace it with a high-quality foreign currency. By doing so, a country will replace a weak (or nonexistent) domestic rule of law with a stronger foreign one. This, of course, will provide a better safeguard for the money used in the country that has abandoned its domestic currency. Not surprisingly, leaders from divergent schools of economic thought have embraced the "dollarization" solution for countries that are incapable of enforcing the rule of law in the monetary sphere. For example, Nobelists Milton Friedman (the leader of the Monetarist School), Robert Mundell (guru of the Supply-Side School) and Friedrich von Hayek (a pillar of the Austrian School) have all advocated "dollarization" in one form or another (Friedman, 1973; Mundell, 1973; Hayek, 1999b).

That said, a few words of caution are in order. The intersection of the rule of law with the coin of the realm implies a monetary rule which allows people to form, with a reasonable degree of certainty, their expectations about the value of money. There are, therefore, a variety of monetary rules that, as a matter of principle, satisfy the rule of law criterion. When, 
however, national monetary arrangements fail to produce stable money and expectations about its future value, those national arrangements fail to comport with the rule of law. In these cases, "dollarization" advances the rule of law and is desirable because it stabilizes expectations.

\section{DOLLARIZATION IN ECUADOR}

Ecuador represents a prime example of a country that was incapable of imposing the rule of law and safeguarding the value of its currency, the sucre. The Banco Central del Ecuador was established in 1927, with a sucre-US dollar exchange rate of 5. Until the 1980s, the central bank periodically devalued the sucre against the dollar, violating the rule of law. In 1982, the central bank began to exercise its devaluation option with abandon. From 1982 until 2000, the sucre was devalued against the dollar each year. (Schuler, 2002) The sucre traded at 6825 per dollar at the end of 1998, and by the end of 1999 the sucre-dollar rate was 20,243. During the first week of January 2000, the sucre rate soared to 28,000 per dollar.

In the case of Ecuador, the inability of the government to abide by the rule of law is, in part, a consequence of traditions and moral beliefs. Ecuadorian politics have traditionally been dominated by elites (interest groups) that are uninhibited in their predatory and parochial demands on the state. (Eifert et al., 2002) With the lack of virtually any moral inhibitions, special interest legislation has been the order of the day. For example, during the rout of the sucre in 1999, laws were passed allowing bankers to make loans to themselves. In addition, state guarantees for bank deposits were introduced. These proved to be a deadly cocktail, one that allowed for massive looting of the banking system's deposit base. (Akerlof and Romei, 1993) This, as well as the collapsing sucre, enraged most Ecuadorians.

With the rule of law (and the sucre) in shambles, President Mahuad announced on January 9, 2000 that Ecuador would abandon the sucre and officially dollarize the economy. The positive confidence shock was immediate. On January 11 - even before a dollarization law had been enacted - the central bank lowered the rediscount rate from 200 percent a year to 20 percent. (Schuler, 2002) But this newfound ray of hope was threatening to some, and during a 24-hour period (January 21-22), a coup d'etat ensued. While the Mahuad government was toppled, the coup was a bungled affair and the former Vice President Gustavo Noboa assumed the Presidency. He honored Mahuad's dollarization pledge. On February 29, the Congress passed the so-called Ley Trolebus, which contained dollarization provisions. It became law on March 13, and after a transition period in which the dollar replaced the sucre, Ecuador became the world's most populous dollarized country on September 13.

With much the same enthusiasm as Ecuador's coup plotters and the rigidity of a dogmatic cleric, the critics of dollarization condemned it as something akin to voodoo economics. My sometime collaborator and a leading dollarization expert Kurt Schuler has compiled a list of some of the condemnations. A small, but representative, sample follows:

\section{International Monetary Fund}

- "Dollarization was not, I must be frank, the kind of policy we would have recommended at this stage to Ecuador. But in these circumstances we are not ideological or systematical in what we do. They have decided that. Now our role is to do everything we can do to help them manage it."-Michel Camdessus (Reuters Newswire, January 17, 2000)

- "Dollarization 'isn't very adequate' under the country's current situation, [IMF managing director Michel] Camdessus said at a press conference during the Third Western Hemisphere Finance Ministers Summit.” (Dow Jones Newswire, February 3, 2000) 
- Dollarization in Ecuador is "one of the riskiest operations we have been involved in." Unnamed "international finance official" (The Economist, April 1, 2000)

\section{Banco Central del Ecuador}

- "The authorities also consider that dollarization and convertibility are not viable schemes at the current moment." (BCE Statement, January 5, 2000)

- "Conditions to dollarize the economy do not yet exist."- Virginia Fierro, manager of the BCE (New York Times, January 12, 2000)

\section{Investment Banks}

- "The problem is, the Ecuadorian economy doesn't have the kind of fundamentals needed to successfully complete dollarization."-Federico Kaune, senior economist, Goldman Sachs (Washington Post, January 11, 2000)

\section{Economic Commentators}

- "Now its [Ecuador's] government has swung to the other extreme and is trying to restore confidence in the currency by abolishing it. Observers say this could work if it is accompanied by extensive domestic reform - which is a bit like saying that you can kill someone with witchcraft it you also give him plenty of arsenic."-Paul Krugman (New York Times, January 19, 2000)

These dire predictions proved to be baseless, but when it comes to commentary on soundmoney currency reforms, they are commonplace. (Hanke, 2002b, 2003) The course of Ecuador's economy has followed the one set by the initial positive confidence shock that ensued after President Mahuad announced his intention to dollarize on January 9, 2000 (see accompanying table). Even the most cursory examination of these data confirms yet again the dictum of Karl Schiller, West Germany's minister of finance (1966-72): "Stability might not be everything, but without stability, everything is nothing." (quoted in Marsh, 1992, p. 30)

It is as if the prophets of doom had plucked their arguments out of thin air. This is astounding. After all, there was (and is) a substantial body of literature on dollarization and its salutary results. Fresh experience from the Balkans was available, too. Acting as President Djukanovic's advisor, I assisted in designing a switch from the Yugoslav dinar-Montenegro was (and is) part of Yugoslavia - to the German mark. This occurred on November 2, 1999, only a few months before President Mahuad's dollarization announcement. This switch was a great success (Hanke, 1999b), ridding Montenegro's citizens of a currency that was even worse than the sucre. To grasp this fact, consider that from January 1991 until 1998, when Slobodan Milosevic was in power, the Yugoslav dinar was officially devalued 18 times and 22 zeros were lopped off that unit of account. (Hanke, 1999a) To put this in perspective, the monthly inflation rate in January 1994 was 313 million percent. Only Hungary, in July 1946, ever recorded a higher rate.

\section{DOLLARIZATION'S DETRACTORS}

In spite of the fact that post-dollarization results have confounded the critics, dollarization's detractors still abound. Many academic economists favor monetary nationalism. (Helleiner, 2003, p. 186-217) They embrace the idea of a central bank and a domestic currency for each country and expound on the alleged shortcomings of monetary unification via the substitution of a foreign currency for a domestic currency. 
TABLE I Main economic indicators for Ecuador, 1998-2003.

\begin{tabular}{|c|c|c|c|c|c|c|}
\hline & 1998 & 1999 & 2000 & 2001 & 2002 & $2003^{*}$ \\
\hline Exchange rate, e.o.p. (sucres per US\$) & 6825 & 20,243 & \multicolumn{4}{|c|}{ Dollarized at 25,000 sucres } \\
\hline GDP (millions of US\$) & 23,255 & 16,674 & 15,934 & 21,024 & 24,311 & 26,745 \\
\hline Growth of real GDP $(\%)$ & 2.1 & -6.3 & 2.8 & 5.1 & 3.4 & 2.7 \\
\hline Inflation (consumer prices, $\%$, sucre base) & 43.4 & 60.7 & 91 & 22.4 & 9.4 & 7.3 \\
\hline Inflation (producer prices, $\%$, sucre base) & n.a. & 186.9 & 64.9 & 6.1 & 5.1 & 3.3 \\
\hline Inflation index, consumer prices, US\$ base (end $1998=100)$ & 100.0 & 54.6 & 83.1 & 101.7 & 111.3 & n.a. \\
\hline Inflation index, producer prices, US\$ base (end $1998=100)$ & 100.0 & 66.6 & 96.4 & 102.3 & 107.5 & n.a. \\
\hline Unemployment rate, e.o.p. (\%) & 11.8 & 15.1 & 10.3 & 8.1 & 7.7 & $10.0^{\wedge}$ \\
\hline Underemployment rate, e.o.p. (\%) & 51.8 & 46 & 49.9 & 34.9 & 30.7 & $49.3^{\wedge}$ \\
\hline Exports (millions of US\$) & 4203 & 4451 & 4927 & 4678 & 5192 & $2933.1 b$ \\
\hline Imports (c.i.f., mn US\$) & 5198 & 2786 & 3469 & 4981 & 6196 & $3024.2 b$ \\
\hline Current account balance (mn US\$) & -2099 & 919 & 916 & -704 & -1178 & $-277 b$ \\
\hline Locally issued monetary base, e.o.p. ([mn US\$]) & 834 & 662 & 261 & 289 & 303.7 & 300.0 \\
\hline Net foreign reserves, e.o.p. (mn US\$) & 1698 & 873 & 1180 & 1074 & 1163.1 & 1492.5 \\
\hline Sucre bank deposits, e.o.p. (mn US\$) & 1919.8 & 862.3 & n.a. & n.a. & n.a. & n.a. \\
\hline Dollar bank deposits, e.o.p. (mn US\$) & 1794.6 & 1554.1 & 3579.9 & 4424.4 & 5009.3 & 4423.4 \\
\hline Money market rate, e.o.p. (\%) & 54.22 & 91.16 & 7.7 & 5.05 & 4.97 & 3.95 \\
\hline Lending rate, sucres, e.o.p. (\%) & 61.4 & 68.3 & n.a. & n.a. & n.a. & n.a. \\
\hline Lending rate, dollars, e.o.p. (\%) & 15.9 & 16.6 & 14.5 & 15.1 & 12.77 & 12.14 \\
\hline Revenue, nonfin. public sector (mn US\$) & 4026.8 & 3515.2 & 4126.1 & 4932.8 & 6271.1 & $1538.8 \mathrm{a}$ \\
\hline —Oil (mn US\$) & 912.9 & 1048.6 & 1460.1 & 1351.8 & 1389.6 & $434.0 \mathrm{a}$ \\
\hline —Social security (mn US\$) & 451.1 & 229.6 & 227.9 & 454.6 & 767.3 & $205.9 \mathrm{a}$ \\
\hline — Value added tax (mn US\$) & 831.2 & 590.8 & 893.4 & 1456.8 & 1666.8 & $436.5 \mathrm{a}$ \\
\hline —Income tax (mn US\$) & 353.8 & 143.6 & 314.4 & 539.8 & 584.0 & $143.8 \mathrm{a}$ \\
\hline —Customs duties (mn US\$) & 592.2 & 310.1 & 216.9 & 354.4 & 413.7 & $85.9 \mathrm{a}$ \\
\hline Spending, nonfin. public sector (mn US\$) & 5144.9 & 4165.1 & 3889.0 & 4852.8 & 6117.2 & $1336.0 \mathrm{a}$ \\
\hline Government debt, e.o.p. (mn US\$) & 15,675 & 16,767 & 14,168 & 14,182 & 14,109 & 14,230 \\
\hline Country risk premium, e.o.p. (\% points) & & 33.5 & 14.2 & 12.54 & 18.01 & 11.14 \\
\hline Average price of West Texas Intermediate petroleum (US\$/barrel) & 14.39 & 19.25 & 30.30 & 25.92 & 26.10 & $31.48 \mathrm{c}$ \\
\hline
\end{tabular}

Notes: $*$ Latest information available, from a variety of dates. ${ }^{\wedge}$ Unemployment and underemployment statistics for 2003 are not comparable to the previous series. $\mathrm{a}=$ first quarter only; $\mathrm{b}=\mathrm{January}-\mathrm{July} ;$ nonfin. $=$ nonfinancial, $\mathrm{c}=$ January-August.

Sources: Banco Central del Ecuador, Boletín Mensual and Boletín Semenal de Coyuntura, at http://www.bce.fin.ec; J. P. Morgan Emerging Markets Bond Index Plus (country risk premium); Haver Analytics (petroleum price).

Source: Schuler (2002), with updates and amendments. 
Hayek warned in 1937 that the budding central banking fad, if it continued, would lead to currency chaos and the spread of banking crises. (Hayek, 1999a) His forebodings were justified. In 1940, there were 40 central banks and today 162 dot the globe. And, as Hayek anticipated, currency and banking crises engulf the international financial system with everincreasing strength and frequency.

The major arguments of the monetary nationalists are manifestly invalid. They are inconsistent with empirical evidence and well-established propositions of elementary economics. The empirical evidence supporting this conclusion has been compiled and is readily available (Schuler, 1996; Hanke, 2002a), and so is a concise critique of the analytical case against dollarization. (Dornbusch, 2001)

A critical evaluation of the academic literature is not possible here. However, a summary of Dornbusch's critique merits comment. First, in most emerging market countries, the socalled national pride that accompanies a domestic currency is little more than a political slogan. (for a contrary perspective, see: Cohen, 1998, p. 35-39) Indeed, most national currencies are a source of national embarrassment and anxiety. This explains why so many countries are unofficially dollarized. (Hanke, 2000) Second, the seigniorage losses from abolishing a domestic currency, while real, are more than offset by the reduction in interest rates and reductions in debt service costs that accompany monetary unification. Third, the loss of monetary policy levers with dollarization is real, but this is a benefit, not a cost. Furthermore, even in the case of a credible emerging-market central bank, the loss of monetary policy discretion is of little practical importance. After all, how many emergingmarket central banks could prudently cut interest rates to levels below those in New York or Frankfurt? The fourth item concerns the loss of a lender of last resort after dollarization. This is nonsense. With dollarization, the lender of last resort exists in the form of credit from the fiscal authorities, the local banking system or the international capital markets. The lender of last resort, with dollarization, forces good market-based credit to be substituted for bad central bank credit. Lastly, without a domestic currency, the fiscal authority will have to stand on its own two feet. True. But by imposing a hard budget constraint, dollarization encourages fiscal prudence. This is a "good," not a "bad," outcome.

In addition to foreign academics, various Ecuadorian groups have voiced opposition to dollarization. Many do so for ideological or opportunistic political reasons. One of the loudest voices of dissent has come from CONAIE, a group that represents indigenous Ecuadorian Indians. Their claims are not only ill-founded, but contrary to the interests of the Indian population in Ecuador. If Indians and other minorities are ever to attain equal rights in Ecuador - which they claim not to possess, but to desire - it will be on the back of the rule of law. Since dollarization has replaced a weak rule of law in the monetary sphere with a stronger one, Indians - as well as all other Ecuadorians - should be shouting from the rooftops with joy.

Ecuador's exporters have complained about dollarization, too. They argue that an "overvalued" dollar has killed Ecuador's export sector. To put it politely, their argument is suspect. Even in the face of slow global growth, Ecuador's exports were higher in 2002 than when dollarization was introduced. Moreover, exports for the January-July 2003 period were up by 16.8 percent compared to the same period in 2002. Baseless whining by exporters is, of course, nothing new. Even though Argentine exports increased in every full year after the peso was linked to the dollar under the convertibility system-except 1999, when Brazil suffered a currency crisis-Argentine exporters unjustifiably complained about an "overvalued" peso. (Hanke, 2003)

So much for the exporters' casual empiricism. The economic argument that Ecuador's exchange rate parity with the US dollar is "overvalued" is simply a result of faulty calculation. Economists calculate real effective exchange rates between currencies by 
comparing the relative movements of prices for tradable goods and services in each country. Accordingly, to make the correct calculation, producer price indices (sometimes called wholesale price indices) should be employed. (Hanke, 2003)

I have made my own calculation of Ecuador's real effective exchange rate using producer price indices in Ecuador and the United States. Ecuador's real effective exchange rate has appreciated by a mere 2.7 percent vis-à-vis that of the US from December 2000 to July 2003. This appreciation represents the actual change in the terms of trade available to exporters. It is clearly not very big. Until exporters get their facts straight, they should not be taken seriously.

In addition, exporters should be reminded of a little history. The exercise of the devaluation option has been the centerpiece of central bank policy in most Latin American countries for decades. In consequence, crises and instability have ensued, and interest rates and the cost of capital have been sky high. Accordingly, modernization and competitiveness have been handicapped and real wages have remained relatively low. With dollarization, stability is established, competitiveness improves and real wages rise because the cost of capital is lower than it is with a junk domestic currency. Dollarization is, therefore, a tonic for both capitalists and their employees.

The cacophonous dissent against dollarization does appear in the press. Indeed, it often crowds out facts and reason. As a currency reform veteran, I have witnessed some truly amazing accounts of currency reforms in which I had detailed, first-hand knowledge. Tales have been spun by the press with threads of disinformation, half-truths and untruths. (Hanke, 2002b) In consequence, I have come to appreciate George Orwell's observation, which he made after recovering from most of his leftist deliriums: "Early in life I had noticed that no event is ever correctly reported in a newspaper, but in Spain, for the first time, I saw newspaper reports which did not bear any relation to the facts, not even the relationship which is implied in an ordinary lie." (Orwell, 1968, p. 256)

That said, I do realize that no policy can be sustained without the support of public opinion and that the press has an enormous influence on the public's beliefs. (von Mises, 1966, pp. 863-64; Hayek, 1999b, p. 132) As a result, it is of utmost importance to set the record straight.

\section{ECUADOR'S CURRENT STATE OF ECONOMIC AFFAIRS}

Dollarization has provided Ecuador with a positive confidence shock, stability and generally good economic results. But successive governments have failed to capitalize fully on the good news. All marketing professionals know that sales campaigns cannot be mounted without either a unique selling proposition (Reeves, 1970) or a great brand image. (Ogilvy, 1985) With the adoption of the dollar, Ecuador was handed both on a silver platter. Accordingly, it could have launched an extraordinary campaign to promote Ecuador.

The Noboa government missed that golden opportunity. That government's ineptitude recalls the Duke of Wellington's characterization of Sir Hew Dalrymple's blunders in Portugal. The Duke wrote in 1808 that "The General has no plan, or even the idea of a plan, nor do I believe he knows the meaning of the word plan." (Rathbone, 1984)

Even worse, the government allowed itself to be entangled in never-ending squabbles with the International Monetary Fund over what amounts to little more than small change, in the broad scheme of things. The result has been a classic marketing disaster, with the economic news coming out of Ecuador being dominated by accounts of the IMF pointing an accusatory finger at Ecuador. While this image of an aggressive prosecutor badgering an accused criminal sells newspapers, it is a public relations nightmare for the one who stands accused. 
Even with the benefit of a home-grown dollarization project, Ecuador has failed to learn the golden rule of reform: Successful reforms are created locally from the bottom-up. They are not imposed by international organizations from the top-down. (Röpke, 1959; Powelson, 1994, pp. 327-41) Indeed, all the major economic liberalizations in the past thirty years have followed that formula for success and have done so under very different political regimes: Chile (undemocratic military government), Britain (democratic, right of center), China (undemocratic, Communist Party), New Zealand (democratic, left of center), and the United States (democratic, right of center). In all cases, reforms were home-grown, bottom-up affairs, with the IMF and other international organizations nowhere to be found.

What, then, is the current state of economic affairs in Ecuador? In a word, they are terrible. Even though the rule of law has been embraced in the monetary sphere, it has been ignored elsewhere. Not surprisingly, the 2003 Index of Economic Freedom categorizes Ecuador's economy as "mostly unfree." It ranks a lowly 118 out of 156. (O'Driscoll et al., 2003) Even by Latin American standards, Ecuador is at the bottom of the heap. Only Venezuela, Haiti, Suriname and Cuba are lower.

\section{AN ECONOMIC FREEDOM MANIFESTO}

Ecuador's economic freedom ranking convincingly shows that liberalism, or neoliberalism as they term it today, has not been applied in Ecuador. This is unfortunate because economic freedom is the engine that drives sustained economic growth. Indeed, GNP per capita is quite sensitive to changes in economic freedom, measured by a variety of indices. For example, a 10 percent increase in economic freedom can be expected to produce an increase in GNP per capita of 7.4 to 13.6 percent. Accordingly, it is not surprising to observe that the level of economic freedom explains 56 to 75 percent of the variation in GNP per capita across countries. (Hanke and Walters, 1997; Berggren, 2003)

By not following the precepts of the rule of law, Ecuador is badly governed, and its economy is over-regulated and inflexible. To change this sad state of affairs and build on the foundation laid by "dollarization," Ecuador should embark on a deep reform program. The following manifesto sketches its elements.

\section{Financial Integration.}

With dollarization, Ecuador entered a unified currency zone with the United States. Ecuador's financial system is still not unified with the United States and the rest of the world, however. It only has four major banks, and for all practical purposes, they are not integrated into the international capital markets. Ecuador cannot, therefore, avail itself of the full benefits of dollarization. Ecuador should follow the lead of Panama and change its banking laws and regulations to facilitate financial integration.

Panama was dollarized in 1904, but financial integration did not occur until 1970. To integrate its banking system into the world's financial markets, Panama changed its banking laws and regulations in 1970. As a result, international banks were attracted. The growth of Panama's banking system attests to the fact that the 1970 banking reforms allowed Panama to take advantage of the trends in globalization and free flow of capital. The banking sector is now 42 times larger than it was in 1970.

At present, 74 banks operate in Panama. Two banks are state-owned and account for 12 percent of the total assets in the banking system. The Caja de Ahorros is a savings and loan 
institution; the Banco Nacional de Panama accepts deposits, is the government's fiscal agent and operates the country's check clearing system. In addition, 29 banks are licensed as international (offshore) banks. They account for 20 percent of the banking system's assets. Over two thirds of the banking system's assets (68 percent) are accounted for by banks that hold general licenses. These banks, which came into existence after the banking reform of 1970, can operate both offshore and in the domestic markets. And among other things, the banks with general licenses can do business with the Panamanian "international" banks that engage exclusively in offshore operations. Panama's dollarized monetary system eliminates its exchange rate risks and the possibility of a currency crisis vis-à-vis the US dollar. And the possibility of banking crises is largely mitigated because Panama's banking system is integrated into the international financial system.

The functioning of the banks that hold general licenses provides the key to understanding how the system as a whole functions smoothly. When these banks' portfolios are in equilibrium, they are indifferent at the margin between deploying their liquidity (creating or withdrawing credit) in the domestic market or internationally. As the liquidity (credit-creating potential) in these banks changes, they evaluate the risk-adjusted rates of return in the domestic and international markets and adjust their portfolios accordingly. Excess liquidity is deployed domestically if domestic risk-adjusted returns exceed those in the international market and internationally if the international risk-adjusted returns exceed those in the domestic market. This process is thrown into reverse when liquidity deficits arise. (MorenoVillalaz, 1999) In consequence, the brutal adjustment mechanism of the sort described by David Hume are avoided. Indeed, departures from zero in the current account are smoothly facilitated by short-term capital flows. (Kindleberger, 1981)

The adjustment of banks' portfolios is the mechanism that allows for a smooth flow of liquidity (and credit) into and out of the banking system (and the economy). In short, excesses or deficits of liquidity in the system are rapidly eliminated because banks are indifferent as to whether they will deploy liquidity in the domestic or international markets. Panama is just a small pond connected by its banking system to a huge international ocean of liquidity. When risk-adjusted rates of return in Panama exceed those overseas, Panama draws from the international ocean of liquidity, and when the returns overseas exceed those in Panama, Panama adds liquidity (credit) to the ocean abroad. To continue the analogy, Panama's banking system acts like the Panama canal to keep the water levels in two bodies of water in equilibrium. Not surprisingly, with this high degree of financial integration the level of credit and deposits in Panama are uncorrelated.

The results of Panama's dollarized money system and internationally integrated banking system have been outstanding, when compared to other emerging market countries.

- Panama's GDP growth rates have been relatively high and their volatility relatively low. This is rather remarkable, when you consider that Panama is a classic dual economy. On the one hand, the services sector (banking) is export-oriented, capital intensive, highly productive, generates little employment and is largely free of government interference. On the other hand, the agricultural and manufacturing sectors are stagnant, highly regulated and subsidized, inefficient, labor intensive and uncompetitive.

- Interest rates have mirrored world market rates, adjusted for transaction costs and risk.

- Inflation rates have been somewhat lower than those in the US.

- Panama's real exchange rate has been very stable and on a slightly depreciating trend vis$\grave{a}$-vis that of the US.

- Panama's system, which operates without a central bank lender of last resort, has proven to be extremely resilient. Indeed, it weathered a major political crisis between Panama and the United States in 1988 and made a strong comeback by early 2000. 


\section{Fiscal Transparency and Control.}

Ecuador's fiscal operations are notoriously opaque and incomplete. Accordingly, there is little fiscal control and accountability. To put its fiscal house in order, Ecuador should adopt laws that mirror New Zealand's Fiscal Responsibility Act of 1994. (Richardson, 1995, pp. 234-43) After all, secrecy is for losers. (Moynihan, 1998, p. 1)

Such a fiscal reform would require Ecuador to publish a national set of accounts, which would include a balance sheet of its assets and liabilities and an accrual-based annual operating statement of income and expenses. These financial statements would be required to meet International Accounting Standards and they would be subject to an independent audit. $^{1}$

Just what is an accrual-based operating statement? At present, accounts in Ecuador are kept on a crude cash basis. Revenues and expenditures are recorded when cash is received or paid out. With accrual accounting, spending and revenues are recorded when they are incurred, regardless of when the money actually changes hands. Accrual accounting gives a much more accurate picture of the realities and avoids many financial tricks that politicians can play with cash accounting. For example, under cash accounting, politicians can promise pensions for future retirees, but since no money is paid until people retire, there are no budgeted costs under cash accounting until the pensions are paid. With accrual accounting, the promises to pay future pensions would appear in the government's accounts when the promises for future obligations are made. Under accrual accounting, the government cannot distort the magnitude of its spending obligations.

In closing this discussion of fiscal transparency and control, a few words about the Banco Central del Ecuador are in order. Even though Ecuador no longer has a domestic currency, it has a central bank with 1200 employees. (Pringle, 2003, p. 51) This is a perfect example of Parkinson's Law: "Work expands to fill the time available for its completion." (Parkinson, 1957 , p. 2) Without a domestic currency, the central bank is no longer needed and should be abolished. Preferably the central bank should be deleted from the constitution, which provides for its existence, but if not it can at least be made a dead letter. Such a change would remove the possibility for monetary mischief at the central bank. For example, small dollardenominated coins could not be minted by the central bank. In addition, the possibility of central bank looting would be done away with. (Weiner, 2003) Any remaining non-monetary activities carried out by the central bank should be transferred to and performed by other units of government.

Without a central bank, the possibility for monetary mischief-including the reversal of Ecuador's dollarization project-would be dramatically diminished. In consequence, risk premiums and interest rates would be reduced.

\section{Tax Simplification and Reform.}

Ecuador's tax system is too complex and the top rates are too high. The top personal income tax rate is 25 percent and the corresponding effective top rate for corporate income is 36

\footnotetext{
${ }^{1}$ The word "audit" brings to mind an interesting anecdote that illustrates politicians' aversion to the mention of that five-letter word:

Hayek once joked as a young man that he would someday like to be president of the Austrian Nationalbank, and while he was in Freiburg during the 1960s, he apparently had the chance. "I was asked by the then righthand side chancellor of Austria, after he had vainly asked Machlup, whether I would be willing to take over the presidency of the national bank, [to] which I assented on one condition, 'If I can engage one of the great international accounting firms to check out the nationalized industries.' That was the end of the conversation! (Ebenstein, 2001: 255).
} 
percent. Ecuador should simplify the tax system and introduce a unified flat tax rate for personal and corporate income, with the unified rate set at between 10 and 15 percent. This would improve incentives to work, save and invest. In addition, it would facilitate better tax administration, improve tax compliance, reduce the time necessary to comply with the tax code and increase revenues generated by income taxes.

Russia's recent experience with a flat tax is most edifying. Starting on January 1, 2001, Russia abandoned the progressive tax system that had been recommended by the IMF. Under the leadership of Vladimir Putin, Russia switched to a flat tax on personal income of 13 percent. Among other things, the tax revenues from the flat tax soared. After adjusting for inflation, revenues were up by 28 percent in 2001 over 2000, by 54.5 percent in 2002 over 2000, and by 80.1 percent in January-June 2003 over 2000. (Rabushka, 2003).

\section{Supermajority Voting.}

For important fiscal decisions, supermajority voting should be established in Ecuador. Many countries require supermajority voting for important decisions. Such a voting rule protects the "minority" from the potential tyranny of a simply "majority." A supermajority voting rule is particularly important for the protection of minorities in countries like Ecuador where the democratic process is not circumscribed by a firm rule of law.

Fiscal decisions are important. The arithmetic of the budget shows us that two new fiscal rules would be sufficient to control the scope and scale of the government and protect minority interests. Total outlays minus total receipts equals the deficit, which in turn equals the increase in the total outstanding debt. Supermajority rules that limit any two of these variables would limit the other variables. Which two variables should be limited? The easiest way to answer the question is to sketch, following Niskanen (1992), an amendment to the Ecuadorian constitution:

Section 1. The total Ecuadorian debt may increase only by the approval of two-thirds of the members of the Congress.

Section 2. Any bill to levy a new tax or increase the rate or base of an existing tax shall become law only by approval of two-thirds of the members of the Congress.

Section 3. The above two sections of this amendment shall be suspended in any fiscal year during which a declaration of war is in effect.

\section{Deregulation.}

Ecuador's economy is wrapped up in red tape and regulations. A big part of the burden for a new business is what might be called the entry tax. How much, in the way of governmentmandated costs, does it take to start a new limited-liability company? This is an important question because new enterprises foster competition.

In Ecuador, government-mandated costs fostered by regulations are onerous and hinder competition. It takes, in principle (not counting bureaucratic delays), 90 days to establish a new limited-liability company. Among other things, a new company must obtain five separate registration numbers. The "start-to-finish" time in Australia, Canada, and the US is only 2, 3, and 4 days, respectively. Accordingly, the costs of starting a new company in Ecuador are high, amounting to 63 percent of an average Ecuadorian's annual income. The comparable costs for Australia, Canada, and the US are 2.0, 0.6, and 0.6 percent, respectively. And in addition to those costs, Ecuadorians are required to provide a minimum capital deposit at a bank equal to 27.6 percent of the average Ecuadorian's annual income. Such minimum capital requirements are not imposed in Australia, Canada, or the US (The World Bank, 2003). 
In addition to these onerous entry costs, the Ecuadorian economy is plagued by regulations that impose undue inflexibility on its labor market, resulting in government imposed unemployment. The procedural complexity associated with the enforcement of contracts is relatively high, too. It takes, on average, 333 days to resolve a contract dispute. This long duration increases the uncertainty associated with the outcome and contracting costs. If this is not bad enough, creditors' rights and bankruptcy laws are relatively weak. (The World Bank, 2003) Accordingly, risk premiums and interest rates are higher than if contracts were easier to enforce and creditors' rights and bankruptcy laws met higher standards.

Ecuador should mount a major deregulation campaign along the lines of that which was implemented in New Zealand. (Brash, 1996) Such a campaign would cut red tape, clarify and improve the rules of the game (for example, in the electric power generating sector) and give the economy a competitiveness boost. (Alesina et al., 2003)

\section{Privatization.}

The public cost incurred in providing a given quantity and quality of output is about twice as great as private provision. This result occurs with such frequency that it has given rise to a rule-of-thumb: "the bureaucratic rule of two." (Hanke, 1987) To sharply reduce the costs of goods and services and enhance Ecuador's competitiveness, government-owned enterprises should be privatized.

The energy sector should be at the top of the government's privatization list. At present, the energy sector (including Petroecuador) suffers from massive waste, fraud and abuse. (Eifert, et al., 2002) This represents nothing more than the "curse of oil." (The Economist, 2003) And Ecuador is not the only country to suffer the ills from the curse, particularly corruption. A sampling of the recent press tells the tale: in the past month, corruption scandals have been reported in Azerbaijan (Chaffin, 2003), Mexico (Silver, 2003), and even Norway (Gibbs, 2003), a country with one of the cleanest government-owned petroleum sectors.

Privatization of the oil sector should be comprehensive, including the current producing oil fields, potential fields and all transportation, storage and refining operations (for sound ideas on how to privatize, see Adelman, 2003; Lee, 2003; Jenkins, 2003).

What should be done with the privatization revenues? First, they should be used to liquidate Ecuador's debt. And second, the remaining revenues should themselves be privatized equitably and distributed to the Ecuadorian people. After all, doesn't Ecuador's oil belong to the Ecuadorian people?

\section{Acknowledgements}

The author thanks Jan Dehn, Jerry Cohen, Bill Niskanen, and Kurt Schuler for their comments.

\section{References}

Adelman, M. A. (2003) Iraq's oil: for sale, to the highest bidder, Wall Street Journal, April 2.

Akerlof, G. A. and Romei, P. (1993) Looting: the economic underworld of bankruptcy for profit. In Brainard, W. C. and Perry, G. L. (Eds) Brookings Papers on Economic Activity, Washington, DC: Brookings Institution.

Alesina, A. et al. (2003) Regulation and investment, NBER Working Paper No. 9560, March.

Barro, R. J. (2000) Rule of law, democracy, and economic performance. In O'Driscoll Jr., G. P. Holmes, K. R. and Kirkpatrick, M. (Eds) 2000 Index of Economic Freedom, Washington: The Heritage Foundation and Dow Jones \& Company, Inc.

Berggren, N. (2003) The benefits of economic freedom, The Independent Review, 8 (2), Fall, pp. 193-211. 
Brash, D. T. (1996) New Zealand's Remarkable Reforms. IEA Occasional Paper 100, London: Institute of Economic Affairs.

Chaffin, J. (2003) Azerbaijan leader implicated in bribery probe, Financial Times, September, pp. 13-14.

Cohen, B. J. (1998) The Geography of Money, Ithaca, NY: Cornell University Press.

de Romilly, J. (2001) La loi dans la pensée Grecque, Paris: Les Belles Lettres.

Dow Jones Newswire (2000) IMF's Camdessus: Ecuador's dollarization not adequate, February 3.

Dornbusch, R. (2001) Fewer monies, better monies, American Economic Review, 91 (2), May, pp. $238-42$.

Ebenstein, A. (2001) Friedrich A. Hayek: A Biography, New York: Palgrave.

Economist (2000) Carnival time again in Latin America?, April 1, US edition.

Economist (2003) The devil's excrement, May 24.

Eifert, B., Gelb, A. and Borje Tallroth, N. (2002) The political economy of fiscal policy and economic management in oil exporting countries, World Bank Policy Research Working Paper 2899, October.

Friedman, M. (1973) Testimony before the Subcommittee on International Economics of the Joint Economic Committee, Congress of the United States, How Well are Fluctuating Exchange Rates Working? 20, 21, 26 and 27 June: $126 \mathrm{ff}$.

Gibbs, W. (2003) Oil company in Norway under cloud, New York Times, 16 September.

Hanke, S. H. (1987) Privatization, In Eatwell, J. Milgate, M. and Newman, P. (Eds) The New Palgrave: A Dictionary of Economics, 3, London: The Macmillan Press, Ltd.

Hanke, S. H. (1999a) Yugoslavia destroyed its own economy, Wall Street Journal, April 28.

Hanke, S. H. (1999b) Most Montenegrins prefer salaries in D-Marks, not dinars, Financial Times, 9 December.

Hanke, S. H. (1999c) Some reflections on currency boards. In Blejer, M. I. and Skreb, M. (Eds) Central Banking, Monetary Policies, and the Implications for Transition Economies, Boston, MA: Kluwer.

Hanke, S. H. (2000) King Dollar, Forbes, 16 October, p. 149.

Hanke, S. H. (2002a) Currency boards, Annals of the American Academy of Political and Social Science, 579, January, p. 87-105.

Hanke, S. H. (2002b) On dollarization and currency boards: error and deception, Journal of Policy Reform, 5 (4), pp. 203-22.

Hanke, S. H. (2003) The Argentine Straw Man: a response to currency board critics, Cato Journal, 23 (1), Spring/ Summer, pp. 47-57.

Hanke, S. H. and Walters, S. J. K. (1997) Economic freedom, prosperity, and equality: a survey, Cato Journal, 17 (2), pp. 117-46.

Hayek, von, F. A. (1944) The Road to Serfdom, Chicago, IL: University of Chicago Press.

Hayek, von, F. (1960) The Constitution of Liberty, Chicago, IL: University of Chicago Press.

Hayek, von, F. (1984 [1978]) Whither democracy? In Nishiyama, C. and Leube, K. R. (Eds) The Essence of Hayek, Stanford, CA: Hoover Institution Press.

Hayek, von, F. (1999a [1937]) Monetary nationalism and international stability. In Kresge, S. (Ed.) Good Money, Part II: The Standard. Volume 6 of the Collected Works of F. A. Hayek, Chicago, IL: University of Chicago Press.

Hayek, von, F. (1999b [1978]) Denationalization of money. In Kresge, S. (Ed.) Good Money, Part II: The Standard. Volume 6 of the Collected Works of F. A. Hayek. Chicago, IL: University of Chicago Press.

Helleiner, E. (2003) The Making of National Money: Territorial Currencies in Historical Perspective, Ithaca, NY: Cornell University Press.

Holmes, K. R., Johnson, B. T. and Kirkpatrick, M. (1997) 1997 Index of Economic Freedom, Washington, DC: The Heritage Foundation and Dow Jones \& Company, Inc.

Jenkins Jr, H. W. (2003) How to lift the curse of Iraqi oil, Wall Street Journal, 14 May.

Kindleberger, C. P. (1981) International financial intermediation for developing countries. In Kindleberger, C. P. International Money: A Collection of Essays, London: George Allen \& Unwin.

Lee, S. (2003) An oil-for-people program, Wall Street Journal, 30 April.

Machlup, F. (1970) Liberalism and the choice of freedoms. In Streissler, E. et al. (Eds) Roads to Freedom: Essays in Honor of Friedrich A. von Hayek, New York: Augustus M. Kelley.

Marsh, D. (1992) The Bundesbank: The Bank that Rules Europe, London: Mandarin.

Moreno-Villalaz, J. L. (1999) Lessons from the monetary experience of Panama: a dollar economy with financial integration, Cato Journal, 18 (3), pp. 421-39.

Moynihan, D. P. (1998) Secrecy: The American Experience, New Haven, CT: Yale University Press.

Mundell, R. A. (1973) Uncommon arguments for common currencies. In Johnson, H. G. and Swoboda, A. K. (Eds) The Economics of Common Currencies, Cambridge, MA: Harvard University Press.

New York Times (2000) Ecuador's 3 top central bankers quit over dollarization, January 12, p. C4.

New York Times (2000) Dollars and desperation, January 19, p. A21.

Niskanen, W. (1992) The case for a new fiscal constitution, Journal of Economic Perspectives, 6 (2), pp. 13-24.

Niskanen, W. (2003) Advice by a friendly American on the proposed constitution for the European Union, Paper presented at a meeting of the European Center for the Study of Public Choice. Rome, 25-27 September.

O’Driscoll, G. P., Feulner, E. J. and O'Grady, M. A. (2003) 2003 Index of Economic Freedom, Washington, DC: The Heritage Foundation and Dow Jones \& Company, Inc.

Ogilvy, D. (1985) Ogilvy on Advertising, New York: Vintage Books.

Orwell, G. (1968 [1942]) Looking back on the Spanish war. In Orwell, S. and Angus, I. (Eds) The Collected Essays, Journalism and Letters of George Orwell, Volume II, New York: Harcourt Brace \& World, Inc. 
Parkinson, C. N. (1957) Parkinson's Law and Other Studies in Administration, Boston, MA: Houghton Mifflin.

Powelson, J. P. (1994) Centuries of Economic Endeavor: Parallel Paths in Japan and Europe and Their Contrast with the Third World, Ann Arbor, MI: University of Michigan Press.

Pringle, R. (Ed.) (2003) The Morgan Stanley Central Bank Directory 2003, London: Central Banking Publications.

Rabushka, A. (2003) The flat tax in Russia and the new Europe, National Center for Policy Analysis Brief Analysis No. 452, 3 September.

Rathbone, J. (1984). Wellington's War: His Peninsular Dispatches, London: Michael Joseph.

Raz, J. (1979) The rule of law and its virtues. In Cunningham, R. L. (Ed.) Liberty and the Rule of Law, College Station, TX: Texas A\&M University Press.

Reeves, R. (1970) Reality in Advertising, New York: Alfred A. Knopf.

Reuters Newswire (2000) IMF boss says Ecuador's dollar plan not its best bet, January 17.

Richardson, R. (1995) Making a Difference, Christchurch: Shoal Bay Press.

Röpke, W. (1959) International Order and Economic Disintegration, Dordrecht: Reidel.

Sally, R. (1998) Classical Liberalism and the International Order, London: Routledge.

Schuler, K. (1996) Should Developing Countries Have Central Banks? Currency Quality and Monetary Systems in 155 Countries. IEA Research Monograph No. 52, London: Institute of Economic Affairs.

Schuler, K. (2002) The future of dollarization in Ecuador, manuscript, September. Available online at http:/ /www.his.com/ ieep

Silver, S. (2003) Arrest warrant issued for Mexican oil union chief, Financial Times, September 25.

The World Bank (2003) Doing Business in 2004: Understanding Regulation, New York: Oxford University Press.

von Mises, L. (1966 [1949]) Human Action: A Treatise on Economics, Chicago, IL: Contemporary Books, Inc.

von Mises, L. (1971 [1912]) The Theory of Money and Credit, Irvington-on-Hudson, NY: The Foundation for Economic Education, Inc.

Washington Post (2000) Use of dollar urged in Ecuador, January 11, p. A11.

Wedel, J. R. (2001) Corruption and organized crime in post-commitment states: new ways of manifesting old patterns, Trends in Organized Crime, 7 (1), pp. 3-61.

Weiner, T. (2003) Ex-leader stole $\$ 100$ million from Liberia, records show, The New York Times, 18 September. 